\title{
HASIL BELAJAR, MINAT DAN KREATIVITAS SISWA SMA PADA PEMBELAJARAN FISIKA MENGGUNAKAN MODEL PROJECT BASED LEARNING DENGAN MEMANFAATKAN BAHAN BEKAS
}

\author{
${ }^{1)}$ Qurrotul Aini, ${ }^{1)}$ Albertus Djoko Lesmono, ${ }^{1)}$ Sri Wahyuni \\ ${ }^{1)}$ Program Studi Pendidikan Fisika FKIP Universitas Jember \\ Email: aini.qr24@gmail.com
}

\begin{abstract}
The purpose of this research was to examine the effect of the model of project based learning by utilizing used materials to the students' learning outcomes, to examine the influence of the model of the project based learning by utilizing the used materials on the interest of learning and to describe the creativity of the students in the model of project based learning by utilizing the used materials. The type of research was experiment using posttest-only control group design. The independent variables in this research was the model of project based learning by utilizing the used materials, the dependent variable in this study is the learning, learning interest, and the students creativity. The result of this research showed that (1) project based learning model using the used materials had significant effect on the students 'learning outcomes, (2) project based learning model using the used materials had no significant effect on students' learning interest, (3) Student learning creativity during use the model of project based learning by utilizing the used materials included in the category quite creative.
\end{abstract}

Key Word: project based learning model, student learning outcame, interests, creativity

\section{PENDAHULUAN}

Fisika merupakan bagian dari ilmu pengetahuan alam yang merupakan usaha sistematis dalam rangka membangun dan mengorganisasikan pengetahuan dalam bentuk penjelasan-penjelasan yang dapat diuji dan mampu memprediksi gejala alam (Peraturan Menteri Pendidikan Dan Kebudayaan Republik Indonesia No. 59, 2014: 900). Fisika merupakan mata pelajaran yang lebih banyak memerlukan pemahaman daripada penghafalan (Septiani et al., 2014) Tujuan pembelajaran fisika adalah dikuasainya kemampuan untuk mengaplikasikan konsep-konsep fisika dalam bidang yang akan ditekuni. Pembelajaran fisika diharapkan dilaksanakan dengan berdasar kegiatan pengalaman langsung melibatkan siswa secara aktif sebagai aktifitas membangun ide dalam memperoleh sesuatu. Dengan aktivitas ini siswa diharapkan memperoleh pemahaman mengenai fakta dan konsep tentang alam serta mengembangkan kreativitas dalam kehidupan sehari-hari (Lindawati et al., 2013: 42).

Faktor yang mempengaruhi prestasi belajar siswa pada suatu pembelajaran ada dua yaitu faktor internal dan eksternal. Salah satu faktor eksternal yang berpengaruh pada prestasi belajar adalah metode/model pembelajaran (Pradita et al., 2015). Pemilihan model pembelajaran hendaknya dapat mengatasi berbagai masalah yang dialami siswa ketika proses pembelajaran (Luthvisari, et al. 2012: 93). Proses pembelajaran dikatakan berhasil apabila ada perubahan-perubahan dalam diri siswa, baik yang menyangkut perubahan pengetahuan, sikap, maupun keterampilan yang dalam prosesnya 
melibatkan interaksi antara siswa dengan guru maupun antar siswa (Maliawan, et al., 2015). Model pembelajaran berbasis proyek (Project Based Learning) merupakan salah satu model pembelajaran yang relevan untuk mengimplementasikan kurikulum 2013 dan dapat mengatasi masalah secara efektif di dalam kelas (Fikriyah et al., 2015)

Kegiatan belajar akan berjalan efektif jika dijalani dengan perasaan senang dan dorongan untuk berpartisipasi dalam pembelajaran dengan kata lain ada minat belajar (Baharuddin, 2014). Minat belajar akan menyebabkan siswa lebih berperan aktif dalam pembelajaran. Partisipasi aktif siswa dalam pembelajaran merupakan proses membangun kemampuan individu dan proses menumbuhkan kreativitas berfikir siswa. Dampak dari hal tersebut adalah peningkatan hasil belajar siswa (Apriniarti et al., 2014)

Model pembelajaran berbasis proyek disebut juga model pembelajaran Project Based Learning merupakan model pembelajaran yang bersifat kontekstual karena diharapkan dapat merubah cara belajar siswa secara mandiri dengan meningkatkan motivasi belajar, meningkatkan kreativitas siswa dalam berkarya, memunculkan ide-ide kreatif serta melatih berpikir kritis, dalam menyikapi suatu masalah yang dihadapi di dunia nyata (Al-Tabany, 2014). Pembelajaran berbasis proyek melibatkan aspek lingkungan tempat siswa berada dan belajar dengan melibatkan kreativitas yang ada dalam diri siswa (Widiyatmoko dan Pamelasari, 2012). Model pembelajaran berbasis proyek melibatkan siswa secara aktif dalam membangun pengetahuannya sendiri serta melibatkan kerja kelompok untuk menghasilkan suatu proyek sebagai aplikasi prinsip atau konsep yang telah diperoleh. Pembelajaran menggunakan model ini membuat siswa terbiasa menemukan sendiri konsep fisika melalui proyek yang diberikan dengan mengkontruksi pengetahuan dalam diri siswa (Sari et al. 2015). Pada model pembelajaran berbasis proyek siswa tidak hanya sekedar tahu namun mampu memecahkan permasalahan, secara relevan dan kontekstual, kooperatif, dan dapat berkolaborasi untuk meningkatkan kemampuan kognitifnya.

Alternatif solusi dibutuhkan untuk membuat siswa terlibat aktif dalam proses membangun pengetahuan pada pembelajaran fisika, mampu meningkatkan minat dan kreativitas siswa dalam pembelajaran untuk mendukung prestasi belajar serta membuat siswa lebih memahami dan dapat mengaplikasikan prinsip dan konsep fisika secara langsung. Pembelajaran berbasis proyek merupakan salah satu model yang melibatkan siswa secara aktif dalam proses pembelajaran fisika yang dapat dijadikan alternatif solusi masalah tersebut. Beberapa kelebihan model tersebut antara lain: meningkatkan motivasi siswa dan membuat siswa menjadi lebih aktif dalam memecahkan masalah (Wena, 2014). Selain untuk menarik perhatian siswa, pembelajaran berbasis proyek juga dapat membuat siswa lebih aktif mengumpulkan informasi baik melalui buku atau media informasi lainnya untuk menyelesaikan permasalahan di dunia nyata (Sani, 2014).

Pembelajaran berbasis proyek memiliki beberapa kelemahan diantaranya yaitu membutuhkan biaya yang cukup banyak (Kemendikbud, 2013: 229). Alternatif solusi yang dapat digunakan untuk mengatasi kekurangan tersebut adalah dengan menggunakan bahan bekas. Keuntungan menggunakan bahan bekas sebagai alternatif solusi adalah bahan tersebut mudah diperoleh dari lingkungan sekitar (Kurniawati et al., 2017), dan pemanfaatan bahan bekas pakai yang tersedia di lingkungan juga dapat dimaksimalkan. Penelitian yang dilakukan oleh Alawiyah (2015) menunjukkan bahwa pemanfaatan bahan bekas juga dapat menunjang sikap ilmiahdan meningkatkan hasil belajar siswa.

Berdasarkan latar belakang tersebut, model project based learning dengan 
memanfaatkan bahan bekas diharapkan dapat berpengarug secara signifikan terhadap hasil dan minat belajar siswa serta dapat meningkatkan kreativitas siswa. Tujuan penelitian ini adalah untuk mengetahui pengaruh model project based learning dengan memanfaatkan bahan bekas terhadap hasil belajar siswa dan minat belajar siswa serta mendeskripsikan kreativitas siswa selama proses pembelajaran menggunakan model project based learning dengan memanfaatkan bahan bekas.

\section{METODE}

Jenis penelitian ini adalah penelitian eksperimen dengan menggunakan postestonly control design. Penentuan tempat penelitian ini menggunakan metode purposive sampling area. Populasi yang digunakan dalam penelitian ini adalah siswa kelas XI di SMAN 4 Jember. Teknik yang digunakan untuk menentukan sampel adalah memilih dua kelas yang memiliki nilai rata-rata ulangan sebelumnya hampir sama.

Teknik analisis data yang digunakan dalam penelitian ini menggunakan uji independen sample t-test dengan bantuan SPSS 20 untuk menguji pengaruh model project based learning dengan memanfaatkan bahan bekas terhadap hasil belajar siswa dan untuk menguji pengaruh model project based learning dengan memanfaatkan bahan bekas terhadap minat belajar siswa. Deskripsi kreativitas siswa merupakan penjelasan kreativitas proses dan produk siswa pada pembelajaran di sekolah selama menggunakan model project based learning dengan memanfaatkan bahan bekas.

\section{HASIL DAN PEMBAHASAN}

Hasil belajar kognitif diperoleh dari nilai post-test pada kelas eksperimen dan kelas kontrol yang dilakukan setelah pembelajaran menggunakan model project based learning dengan memanfaatkan bahan bekas. Nilai tersebut dianalisis menggunakan uji independen sample t-test untuk mengetahui pengaruh model project based learning dengan memanfaatkan bahan bekas terhadap hasil belajar. Hasil uji independen sample t-test diperoleh nilai sig. $(2$-tailed $)=0,000$ yang menunjukkan bahwa terdapat perbedaan yang signifikan antara kelas eksperimen dan kelas kontrol. Dan hasil dari uji pihak kanan menunjukkan nilai sig.(1-tailed) lebih kecil dari 0,05 $(0,000<0,05)$ yang berarti $\mathrm{H}_{0}$ yang berbunyi rata-rata hasil belajar siswa kelas eksperimen sama dengan kelas kontrol ditolak artinya model project based learning dengan memanfaatkan bahan bekas berpengaruh secara signifikan terhadap hasil belajar. Hal ini sesuai dengan hasil penelitian yang dilakukan oleh Amanda et al. (2014) memperoleh hasil bahwa penerapan model pembelajaran berbasis proyek berpengaruh terhadap hasil belajar. Hasil belajar pada penelitian tersebut didefinisikan sebagai hasil belajar pada ranah kognitif yang diperoleh dari nilai post-test.

Penelitian tentang pembelajaran menggunakan model project based learning juga pernah dilakukan oleh Yance dan mufit (2013) yang menujukkan hasil bahwa terdapat perbedaan hasil belajar siswa kelas eksperimen dengan kelas kontrol. Perbedaan tersebut menunjukkan bahwa rata-rata hasil belajar kelas eksperimen lebih tinggi daripada kelas kontrol. Hasil penelitian lain yang mendukung adalah penelitian yang dilakukan oleh Oktadifani et al. (2016) dengan hasil yang menunjukkan bahwa hasil belajar siswa yang menggunakan model project based learning lebih baik daripada siswa yang diajar menggunakan model yang biasa digunakan di sekolah.

Data minat belajar siswa diperoleh dari angket yang telah diisi siswa. Data tersebut dianalisis menggunakan uji independen sample t-test untuk mengetahui pengaruh model project based learning dengan memanfaatkan bahan bekas terhadap minat belajar siswa. Hasil pada 
bagian t-test for Equality of Means pada baris Equal variances assumed diperoleh nilai sig.(2-tailed) $=0,678$ yang menunjukkan bahwa tidak terdapat perbedaan yang signifikan antara kelas eksperimen dan kelas kontrol. Hasil dari uji pihak kanan menunjukkan nilai sig.(1tailed) lebih besar dari 0,05 (0,339>0,05) yang menunjukkan $\mathrm{H}_{0}$ diterima yang berarti rata-rata minat belajar siswa kelas eksperimen sama dengan kelas kontrol dan model project based learning dengan memanfaatkan bahan bekas tidak berpengaruh secara signifikan terhadap minat belajar siswa.

Setelah dilakukan wawancara lanjutan pada beberapa siswa kelas eksperimen yang memiliki nilai minat belajar rendah diperoleh hasil bahwa siswa tersebut tetap tidak menyukai pelajaran fisika meskipun telah menggunakan model project based learning karena siswa tersebut kesulitan dalam menghubungkan konten materi dengan praktek penerapan yang dilakukan. Siswa tersebut masih cenderung beranggapan fisika itu sulit karena terlalu banyak rumus yang harus dihafal dengan berbagai macam simbol dan kurang faham tentang penggunaan rumus tersebut. Sedangkan hasil wawancara pada siswa kelas kontrol yang memiliki nilai minat belajar tinggi menunjukkan siswa tersebut mengisi angket tidak sesuai keadaan siswa pada saat pembelajaran fisika seperti biasanya, siswa tersebut mengisi angket minat belajar sesuai keadaan minat siswa pada saat penelitian dilaksanakan (pada saat bukan guru aslinya mengajar). Minat belajar siswa yang tinggi pada kelas kontrol dipengaruhi oleh perbedaan guru yang mengajar kelas kontrol.pada saat penelitian dengan saat pembelajaran disekolah biasanya. Setiap guru memiliki karakteristik cara mengajar yang berbeda sehingga berpengaruh pada minat belajar siswa.

Model project based learning dengan memanfaatkan bahan bekas tidak berpengaruh secara signifikan terhadap minat belajar siswa. Hal ini tidak sesuai dengan penelitian pembelajaran berbasis proyek yang dilakukan oleh Apriniarti et al., (2014) di SMPN 14 Kota Bengkulu yang menujukkan adanya peningkatan aktifitas, minat, dan hasil belajar siswa.

Dari Tabel 1. data hasil analisis kreativitas proses siswa menunjukkan ratarata dari rendah ke tinggi dengan urutan indikator: keluwesan (flexibility), kelancaran (fluency), kerincian (elaboration) dan keaslian (originality). Sedangkan indikator kreativitas produk dari rendah ke tinggi pada Tabel 2. Menunjukkan urutan kelancaran (fluency), keaslian (originality), keluwesan (flexibility) dan kerincian (elaboration). Secara umum hasil penilaian kreativitas siswa pada tahap proses masuk dalam kategori kurang kreatif sedangkan pada tahap proyek masuk dalam kategori cukup kreatif

Tabel 1. Hasil penilaian kreativitas proses siswa kelas eksperimen

\begin{tabular}{llccc}
\hline No. & Indikator & Ps 1 & Ps 2 & $\begin{array}{c}\text { Rata-rata } \\
\text { indikator }\end{array}$ \\
\hline 1. & Keluwesan & 33.33 & $\begin{array}{c}50.4 \\
8\end{array}$ & 41.91 \\
\hline 2. & Kelancaran & 51.19 & $\begin{array}{c}64.7 \\
6\end{array}$ & 60.48 \\
\hline 3. & $\begin{array}{l}\text { Elaboration } \\
\text { \&originality }\end{array}$ & 39.05 & $\begin{array}{c}88.7 \\
5\end{array}$ & 63.81 \\
\hline & Rata-rata & 42.86 & $\begin{array}{c}67,9 \\
9\end{array}$ & 55.40 \\
\hline
\end{tabular}

Tabel 2. Hasil penilaian kreativitas produk siswa kelas eksperimen

\begin{tabular}{clccc}
\hline No. & Indikator & Pk 1 & Pk 2 & $\begin{array}{c}\text { Rata-rata } \\
\text { indikator }\end{array}$ \\
\hline 1. & Kelancaran & 38.1 & 66.7 & 52.38 \\
\hline 2. & Originality & 80.9 & 42.9 & 61.91 \\
\hline 3. & Keluwesan & 72.4 & 66.7 & 69.53 \\
\hline 4. & Elaboration & 85.7 & 75.2 & 80.48 \\
\hline & Rata-rata & 69.3 & $\begin{array}{c}62.8 \\
6\end{array}$ & 66.07 \\
\hline
\end{tabular}

Data kreativitas siswa diperoleh dari hasil penilaian portofolio dengan cara 
skoring. Penilaian kreativitas belajar siswa hanya dilakukan pada kelas eksperimen saja karena pada kelas eksperimen siswa diberi tugas untuk membuat proyek sedangkan kelas kontrol hanya melakukan percobaan atau eksperimen sehingga kreativitas proyek pada kelas kontrol tidak muncul. Data hasil analisis kreativitas proses siswa menunjukkan rata-rata dari rendah ke tinggi dengan urutan indikator: keluwesan (flexibility), kelancaran (fluency), kerincian, (elaboration) dan keaslian (originality). Sedangkan indikator kreativitas produk dari rendah ke tinggi adalah kelancaran (fluency), keaslian (originality), keluwesan (flexibility) dan kerincian (elaboration). Secara umum hasil penilaian kreativitas siswa pada tahap proses masuk dalam kategori kurang kreatif sedangkan pada tahap proyek masuk dalam kategori cukup kreatif.

Hasil kreativitas siswa masih dalam kategori cukup kreatif dikarenakan siswa sebelumnya belum pernah melakukan pembelajaran dengan cara mengungkapkan berbagai macam ide dalam pembelajaran fisika sehingga cara berfikir siswa untuk mengungkapkan berbagai ide belum bisa berkembang secara baik. Nilai tertinggi rata-rata kreativitas siswa ada pada indikator elaborasi. Hal ini terjadi pada saat siswa membuat proyek. Siswa menjadi aktif dan tertarik untuk menerapkan materi yang sudah dipelajari sehingga siswa berusaha untuk menggabungkan beberbgai unsur untuk menyelesaikan tugas proyek. Jika terjadi masalah pada saat membuat proyek siswa akan berusaha untuk menggunakan berbagai cara untuk menyelesaikan pembuatan proyek. Kejadian yang dapat dijadikan contoh diantaranya adalah pada saat tempat untuk melakukan percobaan terbatas beberapa kelompok siswa melakukan percobaan di halaman sekolah untuk memperoleh hasil yang nantinya akan dibahas pada laporan.

Model project based learning dengan memanfaatkan bahan bekas selain berpengaruh terhadap hasil belajar dan minat belajar siswa juga dapat digunakan untuk mengukur kreativitas seperti yang dilakukan oleh Laila dan Sahari (2016) memperoleh hasil bahwa pemanfaatan bahan bekas sebagai bahan untuk membuat media dapat meningkatkan kreativitas mahasiswa yang meliputi pribadi kreatif, press/dorongan, proses kreatif dan produk kreatif.

\section{SIMPULAN DAN SARAN}

Berdasarkan hasil dan pembahasn pada penelitian ini dapat diambil kesimpulan yang terkait dengan rumusan masalah yaitu: (1) model Project Based Learning dengan memanfaatkan bahan bekas berpengaruh secara signifikan terhadap hasil belajar siswa, (2) model Project Based Learning dengan memanfaatkan bahan bekas tidak berpengaruh secara signifikan terhadap minat belajar siswa, dan (3) kreativitas belajar siswa selama menggunakan model Project Based Learning dengan memanfaatkan bahan bekas termasuk dalam kategori cukup kreatif.

Berdasarkan hasil penelitian dan pembahasan maka saran yang dapat diberikan antara lain: (1) bagi guru diperlukan persiapan yang matang dalam merencanakan proses pembelajaran supaya siswa lebih tertarik untuk mengikuti pembelajaran, (2) bagi guru yang ingin melaksanakan pembelajaran menggunakan model Project Based Learning perlu memperhatikan pembagian alokasi waktu. Alokasi waktu yang digunakan disesuaikan dengan tingkat kesulitan proyek yang dikerjakan siswa, dan (3) bagi peneliti selanjutnya, hasil penelitian ini dapat dijadikan masukan untuk melakukan penelitian lanjutan dengan mengunakan materi yang berbeda atau dengan mengukur variabel yang lain. 


\section{DAFTAR PUSTAKA}

\section{Al-Tabany, T. I. B. 2014. Mendesain Model Pembelajaran Inovatif, Progresif dan Kontekstial. Jakarta: Prenamedia}

Alawiyah, M., Sudarti, dan T. Prihandono. 2015. Pengaruh model pembelajaran projrct based learning berbasis pemanfaatan bahan bekas terhadap sikap ilmiah dan hasil belajar mata pelajaran IPA di MTs Jenggawah. Junal Education UNEJ. Vol.2(1): $37-40$

Amanda, N. W. Y., I. W. Subagia, dan I. N. Tika. 2014. Pengaruh pembelajaran berbasis proyek terhadap hasil belajar IPA ditinjau dari SELF EFFICACI siswa. E-Jurnal Program Pascasarjana Universitas Pendidikan Ganesha. Vol.4(1): 1-10.

Apriniarti, M. S., E. Yunidarvi., dan Sukaryana. 2014. Model pembelajaran berbasis proyek untuk meningkatkan minat dan hasil belajar IPA di SMPN 14 kota Bengkulu. Jurnal Ilmiah. Vol.2(3): 203-214.

Baharuddin, I. 2014. Efektivitas penggunaan media video tutorial sebagai pendukung pembelajaran matematika terhadap minat dan hasil belajar peserta didik SMA Negeri 1 Bajo kabupaten Luwu Sulawesi Selatan. Jurnal Nalar Pendidikan. Vol.2(2): 144-151

Fikriyah, M., Indrawati, dan A. A. Gani. 2015. Model Pembelajaran Berbasis Proyek (Project Based Learning) Disertai Media Audio-Visual dalam Pembelajaran Fisika di SMAN 4 Jember. Jurnal Pembelajaran Fisika. Vol.4(2): 181-186.

Kemendikbud. 2013. Materi Pelatihan Guru Implementasi Kurikulum 2013. Badan Pengembangan Sumber Daya
Manusia Pendidikan dan Kebudayaan dan Penjaminan Mutu Pendidikan Kementerian Pendidikan dan Kebudayaan

Kurniawati, W., dan S. E. Atmojo. 2017 Pembelajaran SAINS bermuatan karakter ilmiah dengan alat peraga barang bekas dan assesmen kerja. Jurnal Pendidikan Indonesia. Vol.6(1): 49-59.

Laila, A., dan S. Sahari. 2016. Peningkatan kreativitas mahasiswa dalam pemanfaatan barang-bekas pada mata kuliah media pembelajaran. Jurnal Pendidikan Dasar Nusantara. Vol.1(2):1-15.

Lindawati, S. D., Fatmariyanti, dan A. Maftukhin. 2013. Penerapan model pembelajaran project based learning untuk meningkatkan kreativitas siswa MAN 1 Kebumen. Jurnal Radiasi. Vol.3(1):42-45.

Luthvisari, N., N. Made D. P., dan S. Linuwih, 2012. Implementasi Pembelajaran Fisika Berbasis Proyek Terhadap Keterampilan Berpikir Kritis, Berpikir Kreatif Dan Kemahiran Generik SAINS. Journal of Innovative Science Education, JISE. Vol.1(2): 92-97.

Maliawan, I. N., I. P. S. Arsa, dan K. U. Ariawan. 2015. Penerapan model pembelajaran project based learning (PjBL) untuk meningkatkan hasil belajar prakarya dan kewirausahaan (fisika terapan) pada siswa kelas $\mathrm{X}$ IPA 2 SMA Negeri 1 Sukasada tahun pelajaran 2014/2015. Jurnal JPTE Universitas Pendidikan Ganesha. Vol.4(1)

Oktadifani, U., A. D. Lesmono, dan Subiki. 2016. Pengaruh model project based learning terhadap keterampilan 
proses SAINS dan hasil belajar siswa dalam pembelajaran fisika di SMA. Jurnal Pendidikan Fisika. Vol.5(2): 109-114.

Peraturan Menteri Pendidikan Dan Kebudayaan Republik Indonesia Nomor 59 Tahun 2014. Tentang Kurikulum 2013 Sekolah Menengah Atas/Madrasah Aliyah. 11 Juli 2014. Berita Negara Republik Indonesia Tahun 2014 Nomor 955. Jakarta

Pradita, Y., B. Mulyani, dan T. Redjeki. 2015. Penerapan model pembelajaran project based learning untuk meningkatkan prestasi belajar dan kreativitas siswa pada materi pokok sistem koloid kelas XI IPA semester genap Madrasah Aliyah Negeri Klaten tahun pelajaran 2013/2014. Jurnal Pendidikan Kimia. Vol.4(1): 89-96.

Sani, R. A. 2014. Pembelajaran Saintifik Untuk Implementasi Kurikulum 2013. Jakarta: Bumi Aksara

Sari, D. Novita, Sutikno, dan Matsuri. 2015. Pengaruh Pembelajaran Berbasis Proyek Terhadap Kreativitas Siswa Melalui Elektroskop Sederhana. Seminar nasional Fisika (E-Jurnal). Vol.4 : 19-24.
Septiani, L. R., Indrawati, dan S. Wahyuni. 2014. Pengaruh model guided discovery terhadap keterampilan proses SAINS dan hasil belajar IPAfisika siswa kelas VII SMP Negeri 1 Jelbuk. Jurnal Pendidikan Fisika. Vol.2(4): 349-355.

Wena, M. 2014. Strategi Pembelajaran Inovatif Kontemporer. Jakarta : Bumi Aksara.

Widiyatmoko, A., dan S. D. Pamelasari. 2012. Pembelajaran Berbasis Proyek untuk mengembangkan alat peraga IPA dengan memanfaatkan bahan bekas pakai. Jurnal Pendidikan IPA Indonesia. Vol.1(1): 51-56.

Yance, R., dan Mufit. 2013. Pengruh penerapan model project based learning (PBL) terhadap hasil belajar fisika siswa kelas XI IPA SMA Negeri 1 Batipuh kabupaten Tanah Datar. Journal of Physics Education. Vol.1(1): 48-54. 